\title{
KEMATANGAN SOSIAL DITINJAU DARI KOMUNIKASI DIADIK IBU DAN ANAK PADA PESERTA DIDIK TK/PAUD
}

\author{
Sri Widyawati.Martha Kurnia Asih
}

\begin{abstract}
ABSTRAK
Penelitian ini bertujuan untuk mengetahui secara empiris apakah ada pengaruh komunikasi diadik ibu dan anak terhadap tingkat kematangan sosial peserta didik TK/PAUD.

Data penelitian dikumpulkan dengan menggunakan Vineland Social Maturation Scale dan Skala Komunikasi Diadik Ibu dan Anak. Sejumlah 33 peserta didik TK/PAUD ikut berpartisipasi sebagai subjek penelitian.

Hipotesis diuji dengan teknik analisis korelasi product moment, menghasilkan $r=0,121$ dengan $\mathrm{p}=0,502(\mathrm{p}>0,05)$. Hal ini menunjukkan bahwa tidak ada hubungan yang signifikan antara komunikasi diadik ibu dan anak dengan kematangan sosial anak, sehingga hipotesis dalam penelitian ini ditolak.

Kata kunci: kematangan sosial, komunikasi diadik ibu dan anak, peserta didik TK/PAUD
\end{abstract}

\begin{abstract}
This study aimed to empirically evaluate weather there is a significant correlation between mother-child dyadic communication and children's social maturation among preschoolers.

Data was collected by Vineland Social Maturation Scale and Motherchild Dyadic Communication Scale. Thirty three preschoolers were participated.

Hypothesis was analysed by product moment correlation technique, resulting $r=0,121$ with $p=0,502(p>0,05)$. The result showed that there is no significant correlation between mother-child dyadic communication and children's social maturation among preschoolers, so that the hipotesis was denied.

PENDAHULUAN

Masa kanak-kanak merupakan masa yang termasuk paling awal dalam rentang kehidupan manusia. Masa ini merupakan masa penting dalam perkembangan hidup manusia, karena masa ini akan menentukan perkembangan pada tahap-tahap selanjutnya. Masa ini adalah masa yang bersifat kritis dimana dasar perkembangan seluruh aspek dalam kehidupan manusia terjadi pada usia kanak - kanak.

Seiring proses tumbuh kembangnya, seorang anak akan melalui tahap-tahap perkembangan dengan tugas perkembangan yang berbeda-beda. Keberhasilan pencapaian suatu tugas perkembangan pada suatu tahap akan membantu kelancaran tahap berikutnya. Sebaliknya, kegagalan pencapaian suatu tugas perkembangan pada suatu tahap akan menghambat penyelesaian tugas perkembangan pada tahap berikutnya. Anak dikatakan berkembang secara normal atau wajar
\end{abstract}


apabila anak dapat menyelesaikan tugas-tugas yang harus dijalaninya pada masa tersebut. Sebaliknya apabila anak tidak mampu menyelesaikan tugas-tugas yang harus dijalaninya maka dapat dikatakan bahwa anak mengalami hambatan dalam perkembangannya. Secara umum, kesesuaian antara perkembangan anak dengan apa yang harus dicapainya dilihat melalui kematangan sosialnya.

Kematangan sosial adalah dimilikinya kemampuan perilaku sebagai kinerja yang menunjukkan kemampuan berpartisipasi dalam lingkungan anak, yang ditunjukkan anak sesuai dengan tahap perkembangannya. Pada usia kanakkanak awal kematangan sosial ditunjukkan dengan perilaku antara lain: mampu menunjukkan sikap bekerja sama dalam kelompok, berani menampilkan diri sesuai dengan minatnya, dapat menunjukkan sikap berbagi, dapat bersikap sesuai norma lingkungan kecil, mampu bersikap simpati dan empati yang masih sederhana, dapat bersikap ramah, tidak egois, suka meniru perilaku positif lingkungannya, serta dapat memberi kasih sayang pada orang yang dekat (Prihaningsih dalam Wulandari, 2008). Kematangan sosial yang dimiliki anak akan mempermudah dirinya untuk berorientasi dan bersosialisasi pada dunia luar yaitu lingkungan masyarakat. Kematangan sosial juga akan mempermudah dalam melakukan hubungan sosial secara mandiri, dalam arti seseorang tidak akan berkembang menjadi individu yang tergantung pada lingkungan sosialnya.

Kematangan sosial seseorang tampak pada perilakunya. Perilaku tersebut menunjukkan kemampuan individu dalam mengurus dirinya sendiri dan partisipasinya dalam aktivitas-aktivitas yang mengarah pada kemandirian sebagaimana layaknya orang dewasa. Kematangan sosial adalah hal yang berkaitan dengan kesiapan anak untuk terjun dalam kehidupan sosial dengan orang lain yang bisa diamati dalam bentuk keterampilan yang dikuasai dan dikembangkan sehingga akan membantu kematangan sosial kelak (Doll dalam Habibi, 2003).

Pengalaman sosial awal sangat mempengaruhi perilaku kepribadian selanjutnya. Banyaknya pengalaman bahagia yang diperoleh sebelumnya akan mendorong anak mencari pengalaman semacam itu lagi pada perkembangan sosial selanjutnya. Dalam penelitian Waldrop dan Halyerson ditemukan bahwa sosiobilitas anak pada umur 2,5 tahun dapat digunakan untuk meramalkan sosiobilitas pada umur 7,5 tahun. Oleh karena pola sikap dan perilaku cenderung menetap maka ada keharusan meletakkan dasar yang baik pada tahap awal perilaku sosial pada setiap anak. Beberapa perilaku yang ditunjukkan oleh anak seperti agresif, daya suai kurang, pemalu, anak manja, perilaku berkuasa, perilaku merusak merupakan indikasi adanya hambatan dalam perkembangan sosial anak. Apabila perilaku itu ditunjukkan oleh anak berusia 2,5 tahun, maka dapat diprediksi begitu pulalah perilakunya pada umur 7,5 tahun. Tentu saja dalam jangka panjang, perilaku tersebut akan dapat merugikan bagi perkembangan kepribadian anak serta merugikan bagi berbagai segi kehidupan yang akan dijalani anak sebagai individu dewasa kelak.

Kebutuhan akan kematangan sosial semakin dirasakan anak ketika mulai memasuki lingkungan yang lebih luas di luar keluarga. Sekolah, misalnya. Di sekolah Kelompok Bermain ataupun Taman Kanak- 
kanak, anak berada di dunia yang di dalamnya terdapat berbagai hal: teman baru, orang dewasa lain selain orang tua dan pengasuh anak, yaitu guru, serta sejumlah kegiatan yang mungkin belum pernah dilakukan anak. Untuk menghadapi ini semua, anak butuh kesiapan fisik, kognitif dan sosialemosional. Jadi, meski kebanyakan Kelompok Bermain atau Taman Kanak-kanak tidak mensyaratkan kemampuan kognisi tertentu, tetapi tetap ada standar yang ditentukan. Misalnya, anak dapat membilang dari satu sampai sepuluh secara berurutan. dan ini berkembang sesuai usia. Anak juga perlu matang secara sosialemosional, mengingat di dunia barunya ini anak dituntut memiliki berbagai kemampuan sosial. Misalnya, kemampuan untuk berinteraksi dengan teman sebaya, memperhatikan guru, mendengarkan orang lain bicara, tidak memotong pembicaraan orang lain, mengekspresikan kemauannya dan bekerja sama.

Ada dua hal penting dalam kemampuan yang perlu dimiliki anak saat hendak masuk Kelompok Bermain ataupun Taman Kanak-kanak, yaitu kemampuan self-help dan social-help. Kemampuan self-help yaitu kematangan anak untuk menolong dirinya sendiri yang di antaranya adalah untuk dapat mengkomunikasikan kebutuhannya. Misalnya, anak dapat mengatakan, "Bu Guru, saya mau pipis". Jangan sampai anak terusmenerus "ngompol" karena tidak berani mengatakan kebutuhannya. Kedua, social-help yaitu kematangan anak untuk mengerti kebutuhan orang lain. Biasanya anak usia prasekolah masih egosentris, yang dipikirkan diri sendiri terus. Kalau barangnya diambil teman, anak akan berteriak-teriak, tantrum dan sebagainya. Kalau anak sudah mengerti kebutuhan orang lain, ia tak akan bersikap seperti ini.

Kematangan sosial pada tiap individu sangat beragam. Keberagaman ini disebabkan oleh adanya interaksi antara faktor internal (nature), yaitu kematangan biologis individu, dan faktor eksternal (nurture), yaitu orang-orang di sekitar individu. Perkembangan sosial anak sangat dipengaruhi oleh lingkungan sosialnya, baik orangtua, sanak keluarga, orang dewasa lainnya, dan teman sebaya. Apabila lingkungan sosial tersebut memfasilitasi atau memberikan peluang terhadap perkembangan anak secara positif, anak akan dapat mencapai perkembangan sosialnya secara matang. Namun apabila lingkungan sosial itu kurang kondusif, seperti perlakuan orangtua yang kasar, acuh tak acuh, sering memarahi, tidak memberikan bimbingan atau teladan, maka tentu saja perkembangan sosial anak ada kemungkinan akan terhambat.

Penelitian ini memusatkan perhatian pada faktor eksternal yang mempengaruhi kematangan sosial anak, yaitu orang-orang di sekitar individu, utamanya ibu. Ibu dipercaya sebagai figure yang menjadi faktor penting dalam tumbuh kembang anak, sejak dalam kandungan (masa prenatal) dan di sepanjang rentang kehidupan anak setelah dilahirkan (masa post-natal). Ibu memberikan pengaruh yang besar melalui kuantitas dan kualitas interaksinya dengan anak melalui pengasuhan. Interaksi antara ibu dan anak meliputi keseluruhan aspek perkembangan, dari perkembangan fisik, kognitif, psikologi dan sosioemosional. Interaksi antara ibu dan anak merupakan suatu proses sosialisasi timbal balik (reciprocal socialization) 
(Santrock, 1995). Interaksi antara ibu dan anak ini sebagian besar berlangsung melalui komunikasi diadik.

Komunikasi yang melibatkan dua orang, dalam hal ini adalah ibu dan anak, disebut dengan komunikasi diadik. Komunikasi diadik merupakan salah satu bentuk dari komunikasi interpersonal. Setiap komunikasi diadik merupakan komunikasi unik yang berkembang dari hubungan diadik yang memiliki sifat unik dalam beberapa hal. Pertama, yaitu bahwa setiap hubungan diadik memenuhi tujuan-tujuan tertentu. Fungsi yang dilayani oleh hubungan ibu dan anak, biasanya akan berbeda dengan fungsi hubungan suami-istri, hubungan gurupeserta didik, ataupun hubungan dokter-pasien. Kedua, yaitu bahwa setiap hubungan diadik melibatkan berbagai sisi yang berbeda dari individu yang berpartisipasi di dalamnya.Tuntutan sebagai peserta didik pada individu dalam hubungan guru-peserta didik, akan berbeda dari tuntutan terhadap individu yang sama saat ia sebagai anak dalam hubungan ibu dan anak. Ketiga, yaitu bahwa dalam hubungan diadik berkembang pola bahasa dan pola komunikasi yang unik, yang membedakan satu hubungan dari lainnya (Ruben dan Stewart, 2006).

Penelitian ini bertujuan untuk mengetahui secara empiris apakah ada hubungan antara komunikasi diadik ibu dan anak dengan kematangan sosial pada peserta didik PAUD X.

\section{TINJAUAN PUSTAKA}

\section{KEMATANGAN SOSIAL} Pencapaian kematangan dalamdalam mengukur kematangan sosial. hubungan sosial merupakan proses yang Aspek tersebut adalah:

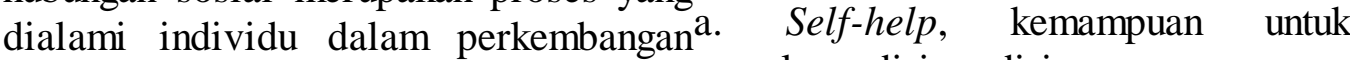
sosialnya.Cha plin (2011) mengartikan menolong diri sendiri.

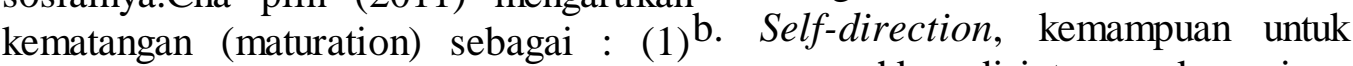
perkembangan, proses pencapai kemasakan/usia masak, (2) proses perkembangan, yang dianggap berasal dari keturunan, atau merupakan tingkah laku khusus spesies (jenis, rumpun). Chaplin juga mendefinisikan kematangan sosial merupakan suatu perkembangan ketrampilan dan kebiasaan-kebiasaan individu yang menjadi ciri khas kelompoknya.

Kematangan sosial merupakan kemampuan individu dalam menyesuaikan diri dengan lingkungannya, serta kemampuan dalam mengerjakan atau menguasai tugas-tugas perkembangannya dengan baik. Orang akan disebut matang apabila telah memiliki sebagian besar dan ciri-ciri kematangan. (Mappiare,1993). Sementara Doll (dalam Firin, dkk, 1994) mendefinisikan kematangan sosial sebagai kinerja yang menunjukkan perkembangan kemampuan dalam memelihara diri sendiri dan kemampuan berpartisipasi dalam aktivitas-aktivitas yang mendukung tercapainya kemandirian sebagai orang dewasa kelak. Selanjutnya ditambahkan olehnya bahwa kematangan sosial adalah hal yang berkaitan dengan kesiapan remaja untuk terjun dalam kehidupan sosial dengan orang lain yang bisa diamati dalam bentuk-bentuk keterampilan yang dikuasai dan dikembangkan, sehingga akan membantu kemandirian sosialnya kelak.

Menurut Doll (dalam Firin, dkk, 1994) ada beberapa aspek yang terkandung dalam kematangan sosial dan aspek-aspek tersebut harus dilihat mengarahkan diri termasuk menjaga 
diri dan merawat barang yang diberikan padanya.

c. Locomotion, kemampuan dan keberanian untuk bergerak.

d. Occupation, yaitu kemampuan untuk mengerjakan tugas yang telah diberikan yang telah diikuti dengan adanya peningkatan proses belajar.

e. Communication, yaitu kemampuan untuk dapat berkomunikasi dengan orang lain.

f. Social-relation, yaitu kemampuan untuk menjalin hubungan dengan orang lain.

Firin, dkk (1994) menyatakan bahwa ada tiga hal yang mempengaruhi kematangan sosial individu, yaitu :

a. Cara pengasuhan

b. Keadaan keluarga

c. Jenis kelamin

Selain itu menurut Hurlock (dalam Indriana, 2008), faktor yang mempengaruhi kematangan sosial di antaranya adalah emosi, intelegensi, budaya, jenis kelamin

KOMUNIKASI DIADIK IBU DAN ANAK

Komunikasi adalah proses penyampaian pesan dari komunikator kepada komunikan yang dapat menimbulkan efek tertentu. Sedangkan komunikasi interpersonal adalah komunikasi antara individu-individu (Littlejohn dalam Rakhmat, 2005). Bentuk khusus dari komunikasi interpersonal ini adalah komunikasi yang melibatkan hanya dua orang secara tatap muka, yang memungkinkan setiap pesertanya menangkap reaksi orang lain secara langsung, baik secara verbal maupun non verbal. Komunikasi yang melibatkan hanya dua orang saja disebut dengan komunikasi diadik. Komunikasi diadik juga terjalin di dalam sebuah keluarga yang melibatkan komunikasi antara anak dan ibu. Komunikasi antara ibu dan anak merupakan media interaksi dari ibu kepada anaknya dalam melaksanakan tugas dan tanggung jawabnya dalam mengasuh, melindungi, membimbing dan mendidik anak.

Hubungan komunikasi yang terjalin antara orangtua dan anak bersifat dua arah yang disertai dengan pemahaman bersama terhadap sesuatu hal. Orangtua dan anak berhak menyampaikan pendapat, pikiran, infomasi atau nasehat (Pratikto dalam Indriyati, 2007). Oleh karena itu, hubungan yang terjalin dapat menimbulkan kesenangan yang berpengaruh pada hubungan yang lebih baik. Hubungan komunikasi yang efektif terjalin karena adanya rasa keterbukaan, empati, dukungan, perasaan positif, serta kesamaan antara orangtua dan anak. Sedangkan kekhususan komunikasi ibu dan anak adalah lebih bersifat pengasuhan. Melalui komunikasi diadiklah ibu menjalankan pengasuhan sekaligus menjadi model bagi proses pembelajaran perilaku sosial anak. Melalui komunikasi diadik ibu dan anak, orangtua memberikan penjelasan atas aturan-aturan sosial yang orangtua tegakkan dan mendorong anak-anak untuk mematuhinya. Anak-anak prasekolah tampaknya merasa aman apabila mengetahui bahwa mereka dicintai dan mengetahui apa yang diharapkan dari dirinya (Papalia, Olds \& Feldman, 2000).

Selama masa prasekolah, keluarga merupakan agen sosialisasi yang terpenting (Hurlock, 1999). Sebagai salah satu faktor yang mempengaruhi tumbuh kembang anak, peran orangtua sebagai lingkungan terdekat anak menjadi sangat penting. 
Seorang anak mempelajari banyak perilaku pertama kali dari orangtua mereka. Bandura (1986) mengajukan teori bahwa sebagian besar perilaku yang dipelajari manusia terjadi melalui proses imitasi/modeling. Teori Bandura selanjutnya lebih dikenal sebagai teori belajar sosial, yang kemudian berkembang menjadi teori kognisi sosial. Proses belajar dalam teori kognisi sosial dari Bandura (1986) terjadi melalui urutan beberapa tahap, yang meliputi tahap perhatian/attentional phase (menaruh perhatian pada perilaku/aktivitas model, dalam hal ini adalah orangtua), tahap penyimpanan dalam ingatan/retention phase (menyimpan hasil pengamatan atas perilaku orangtua dalam ingatan), tahap produksi/production phase (menunjukkan/menghasilkan pola perilaku yang baru berdasarkan perilaku/aktivitas model), dan tahap motivasi/motivational phase (mempertimbangkan apakah akan melakukan/tidak perilaku yang telah dipelajari berdasarkan konsekuensi yang akan terjadi bila perilaku dilakukan). Keluarga, dalam hal ini orangtua, merupakan pemberi contoh atau model mengenai cara-cara menghadapi berbagai tantangan dari lingkungan (Feldman \& Vazquez, 2003).

Sebagai model bagi anaknya, orangtua dapat secara langsung menunjukkan bagaimana cara berkomunikasi yang baik dengan berkomunikasi dengan anaknya. Ketika orangtua tidak dapat berkomunikasi dengan anak-anak mereka, mereka akan kesulitan untuk menyampaikan nilai-nilai, keyakinan, pemahaman, atau kebijaksanaan tentang bagaimana cara mengatasi permasalahan yang dialami. Sementara itu, memasuki lingkungan sosial yang lebih luas lagi, anak-anak merasakan adanya keinginan untuk dapat diterima kelompoknya. Untuk dapat diterima kelompoknya, maka anak harus mempelajari dan kemudian melakukan penyesuaian terhadap harapan sosial yang ada dalam lingkungan sosialnya. Hal-hal yang diharapkan oleh kelompok sosial terhadap anak-anak ditentukan dalam hubungannya dengan tugas perkembangan anak atau pengalaman belajar yang sesuai bagi masing-masing tingkatan usia (Havighurst dalam Hurlock, 1999)

DeVito menyebutkan bahwa efektivitas komunikasi diadik (interpersonal) memiliki karakteristik yang dapat ditinjau dari perspektif humanistik. Dalam perspektif ini ada lima kualitas umum yang dipertimbangkan:

a. Keterbukaan (openness)

b. Empati (emphaty)

c. Sikap mendukung (supportiveness)

d. Sikap positif (positiveness)

e. Kesetaraan (equality)

Dasar dari komunikasi yang baik antara orangtua dan anak, menurut Gottman dan DeClaire (1997) adalah empati, yaitu memahami apa yang dirasakan anak dengan menempatkan diri dan memandang dari cara pandang anak. Anak yang mengharapkan respon yang empatik dari orangtua mereka akan merasa nyaman untuk memulai suatu diskusi tentang masalah yang terjadi, yang kemudian akan meningkatkan kemampuan anak untuk mengatasi masalah tersebut (Brown, Fitzgerald, Shipman, \& Schneider, 2007). Selanjutnya, Gottman dan DeClaire (1997) menyarankan orangtua untuk memberikan bimbingan dalam mendefinisikan emosi yang dirasakan anak dan menerima emosi negatif anak sebagai suatu fakta dalam kehidupan yang dapat digunakan untuk 
memberikan pelajaran yang berharga bagi anak. Gotman dan DeClaire (1997) menyebutkan tipe orangtua yang mampu melakukan hal tersebut sebagai tipe emotional coaching parent. Konsep dasar dari emotional coaching parent ini adalah menyadari ungkapan emosi anak, membangun koneksi, mendengarkan dengan seksama, membantu anak menamai emosi, menetapkan batasan dan menyelesaikan masalah (Gottman \& DeClaire, 1997; Graham 2007).

Berdasarkan pemaparan di atas dapat disimpulkan bahwa komunikasi ibu dan anak adalah komunikasi yang didasarkan pada empati, yaitu memahami apa yang dirasakan anak dengan menempatkan diri dan memandang dari cara pandang anak, dengan menerapkan tipe emotional coaching parent.
Penelitian ini mengacu pada kualitas komunikasi efektif yang dikemukakan oleh DeVito, namun dengan mempertimbangkan pendapat Gottman dan DeClaire berkaitan dengan tahap perkembangan kanakkanak awal. Dengan demikian, aspek komunikasi diadik yang akan digunakan untuk mengungkap variabel komunikasi diadik ibu dan anak dalam penelitian ini adalah aspek empati (empathy), sikap mendukung (supportiveness) dan sikap positif (positiveness).

Hipotesis dalam penelitian ini adalah:Ada hubungan positif antara komunikasi diadik ibu dan anak dengan kematangan sosial pada peserta didik TK/PAUD. Semakin baik komunikasi diadik ibu dan anak maka semakin matang perkembangan sosialnya, dan sebaliknya. 


\section{METODE PENELITIAN}

Penelitian ini merupakan studi populasi dimana populasi dalam penelitian ini adalah peserta didik TKB dari TK Mekar Sari, TK Quantum dan RA Permata Hati, SidokumpulGuntur. Sebanyak 33 siswa didik menjadi subjek penelitian.

Data dikumpulkan dengan menggunakan Skala Kematangan Sosial yang disusun oleh Doll, yang lebih dikenal dengan Vineland Social Maturity Scale (VSMS) dan Skala Komunikasi DIadik.

Data yang diperoleh selanjutnya dianalisis secara statistik menggunakan teknik korelasi product moment dari Karl Pearson.

\section{HASIL \& PEMBAHASAN}

Berdasarkan hasil analisis data dengan menggunakan uji korelasi product moment, diperoleh nilai $r=$ 0,121 dengan $p=0,502(p>0,05)$. Hal ini menunjukkan bahwa tidak ada hubungan yang signifikan antara komunikasi diadik ibu dan anak dengan kematangan sosial anak, sehingga hipotesis dalam penelitian ini ditolak.

Hasil penelitian ini
menunjukkan bahwa tidak ada
hubungan yang signifikan antara
komunikasi diadik ibu dan anak dengan tingkat kematangan sosial yang dicapai oleh anak. Dengan demikian, diambil simpulan bahwa penelitian ini tidak mendukung postulat yang berbunyi Ibu merupakan lingkungan sosial yang sangat penting perannya dalam pencapaian kematangan sosial anak melalui interaksi dengan anak, yaitu komunikasi diadik anak sebagai media pengasuhan.

Benar bahwa lingkungan sosial yang paling awal dan terdekat dengan anak sejak awal kehidupannya adalah keluarga, terutama ibu. Namun demikian, terdapat beberapa pendapat tokoh perkembangan yang juga memberikan penjelasan bahwa perkembangan aspek sosial pada anak tidak semata-mata ditentukan oleh komunikasi yang terbangun antara anak dengan ibu. Faktor eksternal lain juga menjadi determinan penting bagi perkembangan sosial anak. Hurlock menyatakan bahwa salah satu faktor eksternal yang nampaknya cukup menentukan pencapaian tingkat kematangan sosial anak adalah faktor budaya.

Budaya yang dimaksud di sini baik secara luas maupun sempit. Budaya dengan cakupan sempit adalah kebiasaan-kebiasaan yang terbentuk di dalam suatu keluarga, ataupun perubahan kebiasaan yang berkembang secara kolektif dalam suatu lingkungan pemukiman. Berdasarkan informasi yang terkumpul, terdapat kebiasaan yang berbeda yang diterapkan oleh masyarakat di lokasi penelitian. Masyarakat di lokasi penelitian merupakan masyarakat madani. Sebagai lingkungan madani, masyarakatnya sedang mengalami perubahan dari masyarakat agraris menuju masyarakat industri. Fenomena perubahan yang terjadi di antaranya adalah pola interaksi antara ibu dan anak, komunikasi diadik ibu dan anak. Sebagian besar para ibu di lokasi penelitian adalah ibu yang bekerja, secara penuh waktu maupun paruh waktu. Keadaan ini tampaknya berdampak besar pada pola komunikasi diadik ibu dan anak, karena anak menghabiskan sebagian besar waktunya tidak dengan ibu, namun dengan figur pengasuh yang lain. Figur pengasuhan yang terdapat di lokasi penelitian ada yang nenek, paman, bibi, kakak, atau orang lain di luar keluarga yang dimintai bantuan, misalnya tetangga. 


\section{PENUTUP \\ Simpulan}

Tidak ada korelasi yang signifikan antara komunikasi diadik ibu dan anak dengan kematangan sosial anak pada peserta didik TK/PAUD, sehingga hipotesis dalam penelitian ini ditolak

\section{DAFTAR PUSTAKA}

Azwar, S. 2000. Penyusunan Skala Psikologi. Yogyakarta: Penerbit Andi

Chaplin, J.P. 1990. Kamus Lengkap Psikologi. Jakarta: Raja Grafindo Persada.

Davidoff, LL.1991. Psikologi Suatu Pengantar. Jilid Pertama. Alih Bahasa: Jumiati. Jakarta: Penerbit Erlangga.

Gerungan, W.A. 1988. Psikologi Sosial. Bandung: Eresco.

Gunarsa, D.S. 1986. Psikologi Praktis Anak, Remaja dan Keluarga. Jakarta: BPK Gunung Mulia.

Hurlock, E.B. 1999. Psikologi Perkembangan.Suatu

Pendekatan Sepanjang Rentang Kehidupan. Edisi kelima. Jakarta: Penerbit Erlangga.

Irwanto, E.H., Wismanto, B.Y., dan Fernandes. 1996. Psikologi Umum. Jakarta: Gramedia Pustaka Utama.

Purwanto. 1994. Psikologi Pendidikan. Bandung: Remaja Rosdakarya.

Rahmat, J. 1994. Psikologi Komunikasi. Jakarta: Remaja Rosdakarya

Walgito, B. 2002. Psikologi Sosial Suatu Pengantar. Yogyakarta: Yayasan Penerbit Fakultas Psikologi UGM.

Ruben, B.D dan Stewart, L.P. 2006. Komunikasi dan Perilaku
Manusia. Jakarta: PT RajaGrafindo Persada.

Santrock, J.W. 1995. Lie-Span Development. Perkembangan Masa Hidup. Jilid I. Jakarta: Penerbil Erlangga.

Wulandari, A. 2008. Perbedaan Kematangan Sosial Anak Ditinjau dari Keikutsertaan Pendidikan Prasekolah (Playgroup). Tesis. (Online). Diakses

www.distrodoc.com/310138 pada tanggal 14 Februari 2016 Yusuf, S. 2004. Psikologi Perkembangan Anak dan Remaja. Bandung: PT Remaja Rosdakarya. 